\title{
REGION, REGIONALIZATION AND LOCAL DEVELOPMENT
}

\author{
Francesca IMPEI \\ University of Padua, Venezia Ca'Foscari, Verona, ITALY \\ f.impei@outlook.it; francesca.impei@phd.unipd.it \\ DOI: http://doi.org/10.23740/TID220174
}

\begin{abstract}
This contribution aims to stimulate a critical reflection about local development, with particular attention to the role of regionalization practices in the construction of territorial identity processes. It is believed that the identification of specific areas is essential in public policies that aim to promote local specificities, especially in reference to strong areas of excellent territorial capital, not properly valued. This is the case of the Upper Aniene Valley, the study area of my $\mathrm{PhD}$ research project, for which there is no shared regionalization, neither from the scientific world, nor from the political-administrative one, and in which the construction of a shared territorial identity is hindered by the absence of training and information models that allow the people to know the territory where they live or work. In this contribution, after highlighting (in the introduction) the importance of regionalization processes in the social and political construction of space, the case study will be presented, underlining the difficulties encountered during research and in the methodology that is intended to be applied in the regionalization of the Aniene Valley. It is believed that this operation is preliminary to any attempt to intervene in the territory.
\end{abstract}

Keywords: territorial identity, local development, regionalization, Upper Aniene Valley

\section{INTRODUCTION}

Starting from an idea of development based on the uniqueness and self-sustainability of local heritage (Magnaghi, 2010) and on the active participation of local communities in the social production of wealth, this contribution aims to reflect on the meaning of geographical description and of the regionalization processes in public policy and mainly in local development processes. Specifically, I want to reflect on the role of regionalization processes in the construction of identity ones, which are the main topics addressed in my ongoing $\mathrm{PhD}$ dissertation.

It is believed that the identification of specific areas is an important goal in the public policies that aim to promote the territory and local specificities (Governa, 2014; Vallega, 1984; Martin, 2001; Celata, 2008; Rossi \& Celata, 2015; Terlow, 2011; Painter 2008) and that regionalization is a first fundamental step in the process of social construction of space, that Angelo Turco (2010) defines as the "territorialisation process". Through this process, man transforms the natural environment, takes control through clippings and confinements, making a regionalization operation. This practice, which Werlen (2005) defines as "everyday regionalization" is not simply a spatial delimitation operation, but an act of "selective appropriation of the world" (Werlen, 2005), through which the region differs from the surrounding space.

It is clear that the presence of territorial awareness in the local community makes the regionalization processes simpler and more effective; awareness of the limits, but above all of 
the potentials in terms of development and growth of one's own living space in fact enable social relationships and stimulate citizens to feel an integral part of a community and to act in a conscious way for its management and enhancement.

This means that the processes of territorialisation and regionalization are strongly interconnected (Vallega, 1984; Raffestin, 1984) and that the creation of a strong territorial awareness in a community stimulates processes of regionalization and virtuous processes of development on a local scale, especially in areas with strong territorial capital, but not opportunely valorised.

That is the case of the Upper Aniene Valley (the study area of my PhD thesis project), on the eastern edge of the Metropolitan City of Rome, which does not have a regionalization shared by the scientific and political worlds (Banini, 2016). In this sense, the study area is a "soft space" (Paasi \& Zimmerbauer, 2016), with "confused" and easily changeable borders.

The absence of a shared territorial awareness does not allow to delimit "from below" (Paasi, 2003) the Upper Aniene Valley within the territory of the Aniene Valley, not clearly territorially defined, both from the scientific point of view (because of the discrepancy between the various authors' notes) (Banini, 2016), and from the administrative point of view (because of the interweaving and overlapping of the areas of competence).

It is believed that the regional approach could work on the affective, functional and symbolic elements that strengthen people and places, in order to create "territorial cohesion" (Treves, 2004) and to facilitate the activation of active citizenship practices for the management and development of territories.

Therefore, in this contribution, after underlining the importance of regionalization processes in local development policies, the case of the Alta Valle dell'Aniene will be presented, with the aim of demonstrating how the absence of a shared regionalization and at the same time the lack of territoriality constitutes an obstacle to the establishment of innovative development processes.

\section{METHODOLOGY}

Assuming that the identification of land areas is crucial in local development policies (Celata, 2008; Rossi \& Celata, 2015; Governa, 2014; Martin, 2001; Terlow, 2011; Paasi \& Zimmerbauer, 2016) pointing to the "capital of the territory and its peculiarities of identity" (Magnaghi, 2016), it is important to reflect on the concept of region and on the regionalization processes, and not only in Geography.

The discourse on regionalization acquired growing centrality in the most recent European territorial policies, that is about territorialisation of public policies and about the multilevel place-based development strategies (Barca, 2013) oriented to give voice to local territories and their specificities in an integrated and systemic way.

To "territorialize public policies" means to conceive them as "social and political practices" (Paasi \& Zimmerbauer, 2016) that shape space by shifting the decision centre from the national to the locale and by identifying specific typologies and places to act in contextualized modes. This process has been favoured by the consolidation of supranational powers (i.e. the European Union), which choose regions as preferred interlocutors to carry out local development and cohesion policies, contributing to the promotion of new forms of multilevel governance. 
For example, we can consider the central role given to the regions, together with the Member States, in the design of the new cohesion policy axes for the 2014-2020 period and the latest programming experiences and planning (i.e. regional spatial plans) that give centrality to the "local territorial system" (Dematteis \& Governa, 2005) development process. In this regard, we can think to the SNAI (Strategy for Inner Areas in Italy), involving also the Aniene Valley (Inner Area Lazio 3, Monti Simbruini), and/or to the Research Center of the Inner Areas and the Apennines (Air), (http://aria.unimol.it), which are strategies that focus on the collaboration between the various levels of government in a participative growth perspective.

The link between new regionalism and local development is in short need to mobilize the territory, which is considered a strategic component in development processes; so that its definition and delimitation is a prerequisite for the mobilization of forces and actors in the field (Bertoncin \& Pase, 2006). A particular partition methodology imposes specific ways of intervention actors; the establishment of boundaries that include more villages, for instance, symbolizes a desire for institutional cooperation and forces them to work really. From this perspective, the "formal" idea of region is substituted by a systemic, open, and in constant evolution one. This implies "to explore the geography of collective action that is created in places according to a procedural view of the degree of autonomy and innovation of the various territorial systems" (Salone, 2012, p. 169).

\section{Study area: the Aniene Valley}

The Aniene Valley is a cluster of mountain villages on the eastern edge of the Metropolitan City of Rome, on the border with Abruzzo, crossed by the Aniene River, affected by economic marginality and population decline, despite the presence of significant environmental and cultural heritage.

The study area is included in the SNAI -Strategy for Inner Areas (Internal Lazio3-Monti Simbruini Area) as "outskirts" (http://www.dps.tesoro.it) and through projects funded by the European Union, both by the Area (through the co-financing of the 2014-2020 regional operational programmes) and the State (with appropriate resources allocated with stability laws) could be the subject of a development process in which different levels of Government collaborate with local territories from a participatory growth perspective.

The boundaries of the Aniene Valley, however, are not clearly defined and and it is difficult to figure out which municipalities belong to this Valley (Banini, 2016, p. 817). The study area in the geographical literature, as well as in the political field had different administrative demarcations. This allowed to define the spatial scope of the investigation, clearly hampering the data collection and the research information processing.

The presence of scientifically or politically recognized borders would in fact try to delimit the territorial unit, while not forgetting the contrived nature of the regionalization process, which must keep in mind the complexity and heterogeneity of the investigated area.

So, the Aniene Valley is represented by the set of 31 small municipalities of the $10^{\text {th }}$ Mountain Community of the Aniene, with Subiaco as the centre of the area (Figure 1); while the Upper Aniene Valley is a subset whose limits are discussed. 


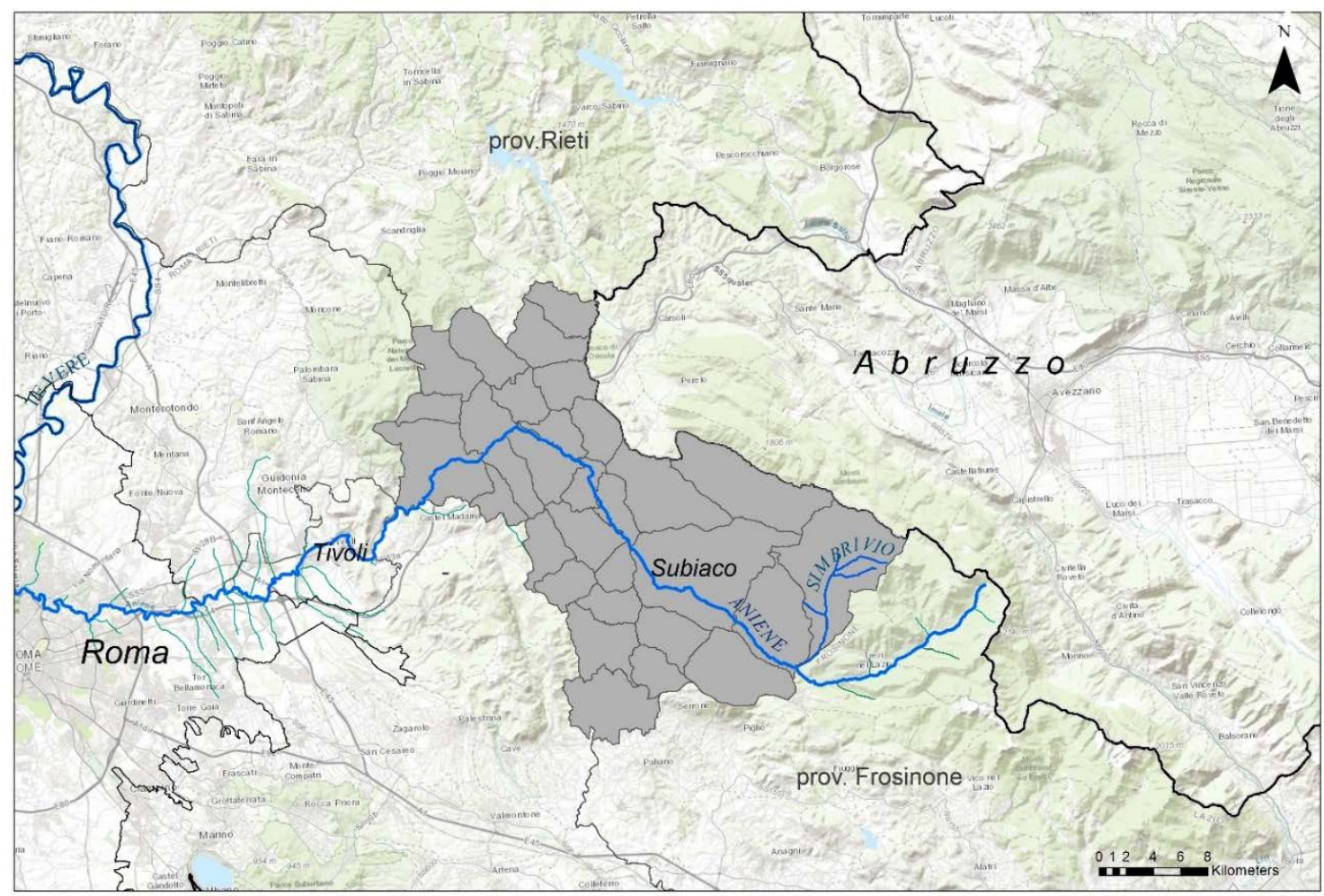

Figure 1: Territorial delimitation of the Aniene Valley on the basis of the municipalities (highlighted in grey) of the $10^{\text {th }}$ Aniene Mountain Community. Scale: 1:250.000. This map was created using ArcGIS ${ }^{\circledR}$ software by Esri

Cartography: Francesca IMPEI, June 2017

From the cartographical point of view, the absence of a place name causes the Aniene Valley to present itself as "an absolute void, suspended between the Simbruini Mountains, the Sabine Mountains, the Monti Ernici and the principal centres of the area (Tivoli and Subiaco)" (Banini, 2016, p. 818) (Figure 1).

\section{What regionalization for the Aniene Valley?}

Given the lack of geographical research on the study area and the absence of a regionalisation of the Aniene Valley shared by the scientific and by the political-administrative worlds (Banini, 2016), during research, it was necessary to reflect on the concept of region and regionalization processes through critical analysis of the international geographical literature and investigate the relational scopes of the Aniene Valley, its boundaries and its internal layouts, with the ultimate aim to identify the region of the Upper Aniene Valley.

This preliminary operation is needed for the study area, where the knowledge of its environment by the community institutions and the local population is poor and does not allow the construction of a process of identity awareness.

If by "territorial awareness" one defines the process through which the stakeholders of a territory gain knowledge of their environment and awareness of its specificity, it is appropriate to ask what could be the right tools to disseminate knowledge and to support the inhabitants 
themselves in structuring and in the evolution of the "system-territory" (Turco, 2010). It is believed that an important role in this regard is covered by digital technologies (i.e. social networks) that facilitate access to information and geographical representation. These tools provide a preferential channel to disseminate information and to build knowledge and awareness; online interaction of the new media - through like, hashtag, friends, status, comment - has become the most common and easiest form of communication to be adopted.

So by searching on the web (social networks and institutional sites), I am getting administrative scopes that characterise the study area, with respect to service management, spatial planning and economic planning, to identify, in referring to regionalisation "from above" (Paasi, 2003), the sub-regions of the Aniene Valley, with particular reference to the Upper Valley.

At this stage, the cartography assumes a fundamental value, as it makes evident the diversity of territorial boundaries in the study area, including those of the past, demonstrating that the regional borders are not "natural" (della Dora \& Minca, 2009, p. 72). Rather the identification of clippings and repartitions establishes a preliminary step in the process of building or strengthening conscious and shared territorial identity among community members.

The makers know no regional theories and, if they know, prefer not to apply them (della Dora \& Minca, 2009). For this reason, the my research project plans to arrange a meeting with local institutions and associations with the aim of presenting the studies carried out in reference to the regionalization of the Aniene Valley. It is believed that the identification of the Aniene Valley and its sub-regions is a preparatory operation to the mobilisation of forces and actors in the field (Bertoncin \& Pase, 2006) and that the use of appropriate methodologies impose the partition of logical specifications for intervention, making a pragmatic tool for choices which relate to the territory, and a symbolic reference in terms of belonging and social cohesion. In particular, the reasoned and contextualized definition of sub-region of the Upper Aniene Valley might stimulate a desire for cooperation between different municipalities that are part of it.

\section{RESULTS AND DISCUSSION}

Field research in the study area is conducted in parallel with a web search and analysis of the pages, profiles and Facebook groups related to the Aniene Valley. This phase is proving useful to check for shared identity factors in political institutions and among the local population, and to identify elements that could help to create a common image of the Aniene Valley and its borders.

The intent is to reflect the "specific sociality" of the network (Castells, 2004) and analyse the interactions that exist between the physical environment (the real places), the social structure (for example, institutions and associations), and electronic networks (Facebook). At a first analysis is emerging a strong presence of intra- and intercommunal relations networks, but they do not concern planning and experiences in favour of the protection and management of the territory, but which express, on the contrary, the desire to share memories and events. So, out of a total of 455 Facebook pages / groups, identified by keyword search (Aniene, Simbruini), only 153 are related to the associations operating in the territory (which deal mostly with sports, culture, and recreation). The remaining pages are managed by individuals and have as main objective the sharing of memories, emotions, and passions. These are groups and / or pages dedicated to sharing old photographs, postcards, documents and iconographic contributions, which depict landscapes of the valley and / or moments of daily life of the past (e.g. users' 
comments, shared and posted photos of the past from their family archives showing enthusiasm).

Specifically, I am trying to ascertain whether and to what extent the locality is interested to take an active and conscious attitude towards the territory in which they live or work and especially if local institutions want to participate in development planning extended to the whole area of the Upper Aniene Valley or even wider territorial systems. Research on social networks will identify potential actors to be mobilized in the process of knowledge dissemination and the kind of data/information that stimulates the users' curiosity, enabling them to become agents of change for the economy of their area (Foray, 2003).

Among the objectives of the project, in fact, there is the creation of a website, which will be like a "square", a virtual meeting place between the inhabitants and operators of the Upper Aniene Valley, who will be able to deeply know their territory and collaborate in its exploitation. The site will be linked to a specially created Facebook page and group. The material that will contain it will be the result of the collection, processing and critical analysis of (1) the geographical literature on the regionalization and local development processes, (2) statistical data (demographic, social, economic, etc.), (3) the plan and thematic maps, and (4) the programmatic documents referred to the study area.

The site will be created at the end of the research phase and will be a useful tool for the community to obtain territorial information and participate in a conscious way to local dynamics, expressing perceptions, proposals, and ideas. The dialogue between users of the site will be facilitated by simplicity and uniformity of language, which will allow the website to be a useful tool for the whole local community, including schools that can use it as an innovative and effective teaching tool.

Given the participatory perspective, the presentation of the site will be an opportunity to realize a series of meetings and events on the territory, aimed at promoting their scope in terms of opportunities to stimulate social cohesion and local planning, facilitating the relationship between the members / actors of the communities.

The creation of the website should, in fact, facilitate the knowledge and awareness of the potential offered by the local territorial capital, to make the inhabitants of the Valley more active in the territorial governance processes through the formulation of ideas and proposals for its protection and enhancement). Stimulating citizens to acquire territorial capital awareness means making sure that the decision-makers have a wealth of knowledge - and knowledge not otherwise obtainable - and take part in a truly "negotiated" territorial action (Rocca, 2010).

\section{CONCLUSIONS}

The centrality of the spatial dimension in public policy and local development processes calls science and politics to discuss regionalization processes and the region, especially with regard to the study and development of those areas with an excellent local capital, but not properly evaluated, as the study area chosen for this research project.

In the specific case of the Upper Aniene Valley, the studies conducted so far show that the absence of regionalization "from above" (Paasi, 2003) has hindered the construction and growth of a conscious and shared territorial identity. At the same time, the absence of territoriality, which generally derives from a strong and conscious territorial identity (but can also be the 
cause of it), has not allowed the development of spontaneous regionalization processes, "from below" (Paasi, 2003), which would have led local actors to feel an integral part of the territory, to weave relations with it through "territorializing acts" (Turco, 2010), distinguishing it from the surrounding space.

It is therefore necessary to start a process of social, conscious and shared construction of the Aniene Valley region and its sub-regions (Upper, Middle and Low Valley); a social and political space, a "system" (open and constantly evolving) in which the forces active on the territory act directly and responsibly for its management and valorisation in the name of a shared identity feeling.

In this sense, for the purposes of this research project, it will be useful to continue analysing the regionalization processes already carried out on the basis of this philosophy, noting the actors who promoted them, the practices in which they materialized and the outcomes that derived from them on the level of social cohesion and localized contextual development. At the same time, it will be extremely useful to continue to investigate the relational domains existing on the territory and on the web, in order to identify potential actors to be mobilized in the construction of space and, therefore, in the responsabilisation process towards their own territory.

\section{REFERENCES}

ALLEN, J., MASSEY, D., \& COCHRANE, A. (1998). Rethinking the Region. London: Routledge.

BANINI, T. (2016). Denominazioni e delimitazioni territoriali. La Valle dell'Aniene nella letteratura geografica. In Romagnoli L. (ed.), Studi in onore di Emanuele Paratore (pp. 817-837). Roma: Edigeo.

BARCA, F. (2013). Aree interne: una strategia per lo sviluppo. FederBim, XXV(2), pp. 23-24.

BERTONCIN, M., \& PASE, A. (eds.) (2006). Il territorio non è un asino. Voci di attori deboli. Milano: Franco Angeli.

CASTELLS, M. (2004). La città delle reti. Venezia: Marsilio.

CELATA, F. (2008). L'individuazione di partizioni del territorio nelle pratiche di sviluppo locale in Italia: ipotesi interpretative. Rivista Geografica Italiana, 115(1), 1-25.

DAVID, P.A., \& FORAY, D. (2003). Economic Fundamentals of the Knowledge Society. Policy Futures in Education, 1(1), 20-49.

DELLA DORA, V., \& MINCA, C. (2009). Regione. In Dell'Agnese E. (ed.), Geografia. Strumenti e parole (pp. 59-84). Milano: Unicopli.

DEMATTEIS, G. (2014). La ricchezza di una disciplina ambigua. In GOVERNA F. (ed.), Tra geografia e politiche. Ripensare lo sviluppo locale. Roma: Donzelli.

DEMATTEIS, G., \& GOVERNA, F. (2005). Il territorio nello sviluppo locale. Il contributo del modello SloT. In Dematteis G., Governa F. (eds.), Territorialità, sviluppo locale, sostenibilità: il modello SloT (pp. 1538). Milano: Franco Angeli.

GOVERNA, F. (2014). Tra geografia e politiche. Ripensare lo sviluppo locale. Roma: Donzelli.

GUALINI, E. (2004). Regionalization as 'Experimental Regionalism': The Rescaling of Territorial PolicyMaking in Germany. International Journal of Urban and Regional Research, 28(2), 329-353.

http://aria.unimol.it (Accessed on 25 August, 2017).

http://www.dps.tesoro.it (Accessed on 25 August, 2017). 
KEATING, M. (1997). The Invention of Regions: Political Restructuring and Territorial Government in Western Europe. Environment and Planning C: Politics and Space, 15(4), 383-398.

KEATING, M. (2001). 'Rethinking the Region. Culture, Institutions and Economic Development in Catalonia and Galicia'. European Urban and Regional Studies, 8, 217-34.

MAGNAGHI, A. (2010). Il progetto locale. Verso la coscienza di luogo. Torino: Bollati Boringhieri.

MAGNAGHI, A. (2016). "Nota su strategie e strumenti di sviluppo locale". Aree interne, nuove economie, Società dei territorialisti/e, Assemblea del 5 febbraio 2016.

MARTIN, R. (2001). Geography and Public Policy. The Case of the Missing Agenda. Progress in Human Geography, XXV(2), 189-210.

PAASI, A. (2003). Boundaries in a Globalizing World. In Anderson K., Domosh M., Pile S., Thrift N. (eds.), Handbook of Cultural Geography (pp. 462-472). London: Sage.

PAASI, A. (2009). The Resurgence of the 'Region' and 'Regional Identity': Theoretical Perspectives and Empirical Observations on Regional Dynamics in Europe. Review of International Studies, 35(1), 121-146.

PAASI, A. (2010). 'Regions are Social Constructs, but who or what 'Constructs' Them? Agency in Question'. Environment and Planning A, 42, 2296-2301.

PAASI, A., \& ZIMMERBAUER, K. (2016). Penumbral Borders and Planning Paradoxes: Relational Thinking and the Question of Borders in Spatial Planning. Environment and Planning A, 48(1), 75-93.

PAINTER, J. (2008). Cartographic Anxiety and the Search for Regionality. Environment and Planning A, 40(2), 342-361.

RAFFESTIN, C. (1984). Territorializzazione, deterritorializzazione, riterritorializzazione e informazione. In Turco A. (ed.), Regione e Regionalizzazione (pp. 69-82). Milano: Franco Angeli.

ROSSI, V., \& CELATA, F. (2015). Ripensare le politiche di sviluppo locale in Italia; un approccio territorialerelazionale. Archivio di Studi Urbani e Regionali, 112, 11-33.

SALONE, C. (2012). Paradigmi e scale territoriali dello sviluppo: il ruolo delle regioni in una politica Placebased. Rivista Geografica Italiana, 119(2), 151-174.

STRATEGIA NAZIONALE PER LE AREE INTERNE: DEFINIZIONE, OBIETTIVI, STRUMENTI E GOVERNANCE. ACCORDO DI PARTENARIATO 2014-2020. Retrieved 2 August 2017, from http://www.dps.gov.it

TERLOW, K. (2011). From Thick to Thin Regional Identities? GeoJournal, 77(5), 707-721.

TREVES, A. (2004). I confini non pensati: un aspetto della questione regionale in Italia. Acme - Annali della Facoltà di Lettere e Filosofia dell'Università degli Studi di Milano, LVII(2), 243-264.

TURCO, A. (1984) (ed.). Regione e Regionalizzazione. Milano: Franco Angeli.

TURCO, A. (2010). Configurazioni della territorialità. Milano: Franco Angeli.

VALLEGA, A. (1984). Assiomatica regionale e regionalizzazione. In Turco A. (ed.) Regione e Regionalizzazione (pp. 277-303). Milano: Franco Angeli.

VALLEGA, A. (1984). Dalla regione alla regionalizzazione: avanzamento teorico e nodi concettuali. In Turco A. (ed.), Regione e Regionalizzazione (pp. 19-45). Milano: Franco Angeli.

WERLEN, B. (2005). Regions and Everyday Regionalizations. From a Space-centred Towards an Actioncentred Human Geography. In Van Houtum H., Kramsch O.E, Zierhofer W. (eds.), B/ordering Space, (pp. 47-60). Aldershot (UK) \& Burlington (VT-USA): Ashgate. 